\title{
Spatial Representations in Charles Dickens's New York and London
}

\author{
Tzu Yu Allison Lin \\ Gaziantep University, Gaziantep, Turkey
}

\begin{abstract}
The purpose of this research is to see the image of New York and London in Charles Dickens's writings. In American Notes (1987), on the surface, the city shows Dickens's eye of observation, revealing the dark side of the city. However, his writing expresses more than what he sees. In this paper, the author sees New York and London not only as realistic accounts of what things look like, but also a true realization of how Dickens feels about himself, and about the country in which he was situated in. In Oliver Twist (2003), a New York prison can be linked to Dickens's London, representing the darkness of the city with the prison cell and its suggestiveness, including punishment, exclusion, and dehumanization. A New York Asylum reveals the dialectic of order and disorder, in a way which alienation brings out the crisis of humanity. This research shows that New York is an extension of London, in a way which the personal crisis is vividly revealed, as the reader can see in Charles Dickens: A Life (2012). Through New York, Dickens is more conscious about his London childhood, as spatial representations of London have their own symbolic meanings.
\end{abstract}

Keywords: Charles Dickens, New York, London, space, representation, prison, insanity

\section{Introduction}

In this paper, the author deals with an issue, which is essential to the study of Charles Dickens's writings. Critics usually focus on the image of the city of London, in a way which they found Dickens and his novels were best known. And yet, the author argues that Dickens's American Notes (1987) also plays a critical role in Dickens's writing career. It takes a form of travel writing, but it does not only show an ordinary tourist's point of view. Dickens's New York, in his writing, expresses a particular perspective of how this Victorian writer sees himself and his own past as an internationally celebrated writer. His New York is significant, because through that city, the reader can see the way in which Dickens comes to connect to his childhood memory in London through writing.

\section{America}

The image of America seems to be a fairy land for the British travelers. Daniel Defoe's most famous character, Robinson Crusoe, has travelled to "an un-inhibited island on the Coast of America” (Defoe, 1998, title page), as in his title page of the novel Robinson Crusoe shows. Although Crusoe's trip was not to the continent

Tzu Yu Allison Lin, Ph.D., assistant professor, Department of Foreign Language Education, Gaziantep University. 
itself, the spirit is to travel and to see a different kind of world, such as Charles Dickens himself, as a Victorian traveler, would do. Dickens's American Notes may not be as well-known as his other fictional writings about the city of London. According to Grubb’s American Notes (1950), “appeared in London on October 18, 1842” (p. 101). In general, the reviewers do not like it. One of the "unfavorable reviews” even says that this work of Dickens's "has no real literary value” (Grubb, 1950, p. 101).

Dickens may be able to use his travel experience later in his novels, as Meckier (1984) points out, to "[transform] an unsatisfactory England into that best of all possible worlds he had hoped to discover in America” (p. 273). Stone (1957) also claims that Dickens's travel experience in America, is certainly not purposeless and useless. Dickens's American Notes can be read as a way, in which one can see "his artistic methods and limitations" (p. 464). To be more precise, as Heilman (1947) puts it, the American experience is Dickens's "source of materials to be used in satirizing Europe” (p. 21), in his later writings. At the first glance, in general, American Notes shows that Dickens "became disenchanted with many things American” (Waller, 1960, p. 535). There may be rumors about why Dickens "became soured upon American manners" and "customs" (Grubb, 1951, p. 87). And yet, the author would argue that his image of New York is certainly worth a discussion in depth.

\section{New York and Dickens's Dual Vision}

Dickens's perspective of the city of New York indicates a double ways of seeing —First of all, he sees people and things as what an outsider or a traveler can possibly see; and second, he sees the city as a representation of a part of his personal history. More precisely, this personal history refers to his memory as a young man. This dual way of seeing a city represents his own thoughts and feelings, as Dickens's narrative forms a threshold between his own self and the narrator in the travel writing. Spaces of New York City are filled with metaphorical meanings. But the question is, why are these images significant?

The image of Charles Dickens's New York City is a "witch’s cauldron”, which is "hot”, "suffocating”, and "vaporous" (Dickens, 1987, p. 142). Just as Poe (1996) points out in his short story, "The Man of the Crowd" (1840), there are certain books which are not suppose to be read, "[t]here are some secrets which do not permit themselves to be told” (p. 388). Here, the author would like to add up one more thing-the city of New York, in Dickens's narrative, is a city which does not permit itself to be visited.

Poe's man of the crowd is an observer. This man seems to be indicating Charles Baudelaire's image of the flâneur, which is a representative figure, finding himself " $\mathrm{t}$ ]o be away from home and yet to feel oneself everywhere at home; to see the world, to be at the centre of the world, and yet to remain hidden from the world" (Baudelaire, 1995, p. 9). As a traveler, Dickens has his own friends who are able to take him around the city, so that he can feel free to see whatever he wants to see. Although he does not tell his readers whos these "friends"1 are, we can be sure that he is "grateful" to have their company, without even mentioning about any of their names, as he writes in the 1859 Library Edition Preface. These friends make Dickens's observation of New York City possible, as he travels and becomes a man of leisure, when he visits places such as Music and Dance Halls for

\footnotetext{
${ }^{1}$ According to Tomalin (2012), Washington Irving was one of the friends, who "spoke in his praise" in "the New York Dickens Dinner". Dickens had a chance to meet Irving "almost daily", for taking the issue of "international copyright to the Congress". Cornelius Felton was also with Dickens most of the time in New York, together they visited "a great many oyster cellars" (p. 132).
} 
entertainments. He is also engaged in seeing places he wants to see, particularly Institutions such as prisons and mental hospitals.

The streets of New York City have their own textual and social meanings. Broadway is the first street, which Dickens addresses, when he stays in "the upper floor" of "the Carlton House Hotel" (Dickens, 1987, p. 128). Dickens could gaze at the stream of life on the street from his window. This stream of life shows Broadway as "a sunny street". Dickens's hotel room window is burning because of the heat of the sun, through which, in "ten minutes” time, he sees all kinds of well-dressed ladies, and their colorful parasols. Black and white coachmen are in different colors and styles of hats:

In straw hats, black hats, white hats, glazed caps, fur caps, in coats of drab, black, brown, green, blue, nankeen, striped jean and linen; and there, in that one instance (look while it passes, or it will be too late), in suits of livery. (Dickens, 1987, p. 128)

In Dickens's writing, one can see that he seems to be taking a picture through his hotel room window as a traveler can do, as his eye becomes a symbolic camera eye, looking at people's movements and their fashion styles as they pass. As a traveler, his mood is cheerful, since Broadway is so sunny, as:

[T]he pavement stones are polished with the tread of feet until they shine again; the red bricks of the houses might be yet in the dry, hot kilns; and the roofs of those omnibuses look as though, if water were poured on them, they would hiss and smoke, and smell like half-quenched fires. (Dickens, 1987, p. 128)

The heat of Broadway feels just like Dickens’s passion of looking at the crowd, as the adventure of walking around New York City has just begun.

And yet, the bright vision and the cheerful mood of Dickens's, after a while, turn to an image of horror, when he walks along Bow Street. This street represents an area, which is full of "narrow ways, diverging to the right and left, and reeking everywhere with dirt and filth” (Dickens, 1987, p. 136). This is one of the worst places in Dickens' New York, because it is very dirty and filthy. For instances, the houses here are "prematurely old. See how the rotten beams are tumbling down, and how the patched and broken windows seem to scowl dimly, like eyes that have been hurt in drunken frays” (Dickens, 1987, p. 136).

Houses seem to indicate the condition of people who live there. Apparently, people live in Bow Street are not very healthy, and they look old and shabby. The windows of their houses are "broken", as if those people are as drunk as "pigs" (Dickens, 1987, p. 136). Their eyes have been injured because they are unconscious and drunk. Dickens's hotel room window in Broadway seems to be perfect. To compare to other people who live in different areas of New York, people in Bow Street cannot even be named in human terms — even the place they live is like a "wolfish den” (Dickens, 1987, p. 137). There is this "Negro" (Dickens, 1987, p. 137) lives in this "miserable room", among one of the "squalid street" and a "square of leprous houses" (Dickens, 1987, p. 137). In Broadway, there are black men and white men. At least they all look like human beings. But here, black man is a nameless "Negro", with a socially insignificant fever in his head. In the bottom of the social class, this person does not even bother to "look up", when the officer asks him for what happened to him (Dickens, 1987, p. 137). Dickens's term "Negro" here suggests the man's being black. It has a stronger implication of Dickens's discontent of "[t]he barbarity of the slavery system" (Pound, 1947, p. 124), as he sees "the horrors of the system” (Dickens, 1987, p. 269). 
The term "Negro" is particularly meaningful, when in the context of Southern America, as people can "own, breed, use, buy and sell” their slaves (Adrian, 1952, p. 319). As Claybaugh (2006) points out, "British antislavery activities offered their American counterparts moral example, financial support and practical advice. This support peaked in the early 1840s, at the moment when Dickens made his tour of the United States” (p. 444). Here the author's point is, the general impression of America, in Dickens's writing, seems to be rough and barbaric. Clearly, the general condition of the way in which people live is not as good as Dickens has expected-to a least expectation of a human being's living condition. Although it is not particular necessary to see Dickens's American Notes as a "propaganda for reform" (Goldberg, 1972, p. 74), still, the author can see more about the human conditions in America that Dickens has noticed. For Dickens, in some areas of New York, people—including white or black, men or women, their way of living makes them all look like animals, as he noticed, "Such is life: all flesh is pork!" (Dickens, 1987, p. 134). In some certain extreme social conditions, the way people live represents them as only different kinds of “pigs” (Dickens, 1987, p. 134), or “a pig’s likeness” (Dickens, 1987, p. 134).

These people's situation seems to be indicating Dickens's moment of Dickens's own awakening, especially, when he sees the "colour prints of Washington, and Queen Victoria of England, and the American Eagle" on the wall of these "pigeon-holes” houses (Dickens, 1987, p. 136). It is hard to tell, from Dickens's writing, how people in New York feel about Queen Victoria. And yet, the contrast between monarchy and "an American form of Government, with an elective head of State” (Benson \& Esher, 1907, p. 640), is still there. According to the King of the Belgians, in his letter written in Laeken, on 15th December 1843, to his niece Queen Victoria, the reader can see that some people in England, "for some years", thought "that Royalty was useless and ignorant" (Benson \& Esher, 1907, p. 639). The color prints of Queen Victoria of England on the wall in the street of New York, certainly brings out "a very aristocratic feeling” (Benson \& Esher, 1907, p. 640).

It seems that both worlds, across the Atlantic, are each other's counterparts. The King of the Belgians remembered that there was "a very rich and influential American from New York", he thought that the Americans need "a Government which was able to grant protection to property, and that feeling of many was for Monarchy instead of the misrule of mobs” (Benson \& Esher, 1907, p. 640). In Dickens’s New York, ironically enough, images such as "designed ships, and forts, and flags, and American Eagles out of number" can particularly be seen in those poor areas, in a way which the rich American man from New York in the letter of the King of Belgians, seems to have a point. These colorful images of American dreams come to make a sharp contrast with the reality of the visible world of New York City — the area of "ruined houses, opened to the street, whence, through wide gaps in the walls" (Dickens, 1987, p. 138). The "wide gaps" of the walls seem to ironically indicate the "gaps" between the dream image and the visible reality, reinforcing the ambiguity of the private and the public spheres, as the houses are opened to the street.

\section{The Victorian Prison and Insanity}

Dickens has made a decision of leaving America and going back to England, when he was in New York. Most probably, he realizes that home is not perfect, but it seems to be at least livable. This City of New York, in his eyes, is nothing more than a broken dream. Visiting a Lunatic Asylum in Long Island area, Dickens was again, painfully shocked by the "naked ugliness and horror" of human faces and human conditions. A typical one is 
called the "moping idiot", with "long disheveled hair", "the gibbering maniac", "hideous laugh and pointed finger" (Dickens, 1987, p. 140). The wall of the dining-room is "empty", "with nothing for the rest of the eye to rest". Among these "bare, dull" and "dreary" spaces, the author would argue that Dickens sees a sadness of this "refuge of afflicted and degraded humanity" (Dickens, 1987, pp. 140-141). The true meaning of American spirit, here in Dickens's eyes, is something as hot and as dry as a desert, "sickening and blighting everything of wholesome life with its reach" (Dickens, 1987, p. 141). New York seems to be the most of it, with the "crowd" of terror in the "madhouse". The threshold of the mental hospital reveals Dickens's feeling of "deep disgust and measureless contempt” (Dickens, 1987, p. 141). It is a threshold of non-returning, no matter physically or spiritually. Dickens does not even look back again.

Home is not perfect, but as least it has a sense of humanity. Dickens's observation of prisons in New York, once more, makes readers see the vivid image of a kind of human-as-animal way of living. Even prisons back home in England, for Dickens, treats the prisoners as human beings, instead of caged chickens. For example, Dickens sees this man of 60 years old, who "has murdered his wife, and will probably be hanged" (Dickens, 1987, p. 132). Dickens depicts this man in his "small bare" prison cell, in a way which shows that this man is like an actor on the stage, with a spot light coming from above, as "the light enters through a high chink in the wall" (Dickens, 1987, p. 132). The wall of this prison cell indicates the consciousness of the man and his thought, when he is reading in this "four walled room" (Benjamin, 1973, p. 37). And yet, ironically, this man is not allowed to walk freely in the city, unlike the flâneur. He looks up at Dickens's eyes, "for a moment", but soon he "gives an impatient dogged shake; and fixes his eyes upon his book again” (Dickens, 1987, p. 132).

Dickens (1987) tells the officer, that "[i]n England, if a man be under sentence of death, even, he has air and exercise at certain periods of the day" (p. 132). Dickens (1987) also notices that there is a "lonely child, of ten or twelve years old" also in another prison cell. He is again in deep shock, when he realizes that this boy is the son of that reading man. The function of this boy is to be "a witness against his father" (p. 132), but he is also treated as a prisoner, staying in a separate cell for a month.

The child "of ten or twelve" in the city prison of New York, most probably makes Dickens thought about his own childhood. It was almost twenty years ago before he visited America. According to Angus Calder, in the year of 1823, Dickens's “family moved to London, faced with financial disaster”, because Dickens's father John Dickens "had been arrested for debt, and soon the whole family, except for Charles who was found lodgings, joined him in the Marshalsea Debtors' Prison” (Calder, 1987, p. 7). Although Dickens did not join the family in the prison, and yet, according to Calder, this "family shame" "transformed him", "which haunted him till his death" (Calder, 1987, p. 7). The shameful feeling is like the shadow under the long and thick "brick structure" of “the Marshalea's wall” (Tagholm, 2001, p. 172). This boy in the city prison of New York happens to have a similar age with Dickens's, when his family was in prison. Dickens had the feeling of humiliation not only because of his father's being in prison, as "the buildings were old and shabby" (Tomalin, 2012, p. 23), but also before that had happened in February 1824, the family was "pursued by creditors with increasing ferocity, their furious knockings and shoutings at the front door driving his father to ignominious hiding places upstairs" (Tomalin, 2012, p. 22). Dickens, "as the man of the family, just twelve years old”, had absolutely “[n]o help” from any other family members—not even from his uncle William Dickens who owned a coffee shop in Oxford Street.

At Warren's factory, “young and sensitive” Dickens had to use his "lunch hour to keep up his education” 
(Tomalin, 2012, p. 24), while his parents did not care about the importance of his being educated. As Tomalin explains, Dickens’s experiences:

Of debt, fear, angry creditors, bailiffs, pawnbrokers, prison, living in freezing empty rooms and managing on what can be borrowed or begged-were impressed on his mind and used again and again in his stories and novels, some-times grimly, sometimes with humour. (Tomalin, 2012, p. 23)

As the reader can see the "realistic milieu” (Lankford, 1978, p. 20) of London in Oliver Twist (2003).

Dickens's walk in the city prison of New York, comes as a symbolic walk into his own personal history. The prison boy can be seen as a form of child labour, since he is there not for his criminal behavior, but for watching his father. The situation of this boy, somehow reminds in Dickens himself, that his memory of his early form of child labor, as "[t]wo days before his twelfth birthday, the boy began work as a factory at Hungerford Stairs, labelling bottles for six shillings a week” (Calder, 1987, p. 7). Dickens’s illustration of New York may only be a very small part of his American Notes, and yet, it shows his emotions and his feelings about New York, in a way which his words and his self are strongly connected. In January 1840, the "young woman prisoner” from Marylebone Workhouse was “accused of killing her newborn baby in the kitchen of her employers’ house” also made Dickens upset, because of the "terrified, ignorant, unhappy” (Tomalin, 2012, p. xii) servant girl and her missing baby. It reminds him a feeling of “powerless,” facing a “traumatic situation” (Freud, 1959, p. 170) of loss and pain, as what he had been through when he was 12, just like his character Oliver and his "helpless position of a child,” while facing “terror and uncertainly” (West, 1989, p. 46).

\section{London, Prison: Oliver Twist}

As Werner and Williams (2011) once claimed:

Dickens's word-pictures of London did not simply describe a backdrop, a stage set, upon which the novelist's artfully-drawn characters world play out their lives, loves, hates and fears. London itself is a central presence in the novels, a character in its own right. (p. 7)

For the author, Dickens's London prison in Oliver Twist, recognizing by Kincaid (1968) as "a dark novel" (p. 63), provides one of the best examples for this statement. In Chapter the Fourteenth, “The Jew’s Last Night Alive", the reader can see the way in which Dickens made his verbal portraits of the prison and the prisoner "a spectacle” (Dickens, 2003, p. 446). The prison is depicted as a fearful space, representing crisis and the painful experience which Dickens had in his childhood. The prison in Oliver Twist has a "death-like stillness" (Dickens, 2003, p. 441), urging a feeling of anxiety. The prisoner is left "alone" in one of "the condemned cells" "through a gloomy passage, lighted by a few dim lamps, into the interior of the prison” (Dickens, 2003, p. 443).

As Foucault (1991) has stated in his book Discipline and Punish: The Birth of the Prison, the purpose of putting a criminal in prison is to let one "pay one’s debt” (p. 233) by losing one’s own freedom. Imprisonment is a situation, according to Foucault (1991), which shows a "self-evident" character of the prison in a form of “deprivation of liberty" (p. 232). The prisoner is like a beast in its cage, ruling by "silence” (Foucault, 1991, p. 238). Silence and isolation are very important. Through the form of "absolute isolation" and silence, it is possible to have some sort of enlightenment "from within" (Foucault, 1991, p. 238), in a way which one can achieve "a change of 'morality’” (Foucault, 1991, p. 239). In Dickens’s (2003) narrative, the prison cell is very dark, 
depicting an illusion of many prisoners' "last hours", as if the Jew can see "the faces" "beneath that hideous veil", when light is "desperately needed" (p. 445). The death sentence has been decided by the court. It gives no time for the Jew to think about morality. All he has is endless fear, in the long night and "in its dreadful silence", counting by "the church-clocks strike", as "[t]he boom of every iron bell came laden with the one deep hollow sound-Death” (Dickens, 2003, p. 445).

As Frederick (1966) has claimed, "the image of evil [Oliver Twist] presents is far more forceful than that of the ostensibly triumphant good” (p. 465). Like Dickens’s New York prison, this prisoner is under the gaze of a young boy-Oliver. The prisoner represents a sight of horror himself, "in such a paroxysm of fear and wrath", as he "grew so terrible at last in all the tortures of his evil consciousness" and the "full intensity upon his blighted soul” (Dickens, 2003, p. 446). It is indeed, “not a sight for children” (Dickens, 2003, p. 447). But according to Mr. Brownlow, Oliver is "intimately connected with" the Jew. As a child, Oliver "has seen him in the full career of his success and villainy” (Dickens, 2003, p. 447). Just like the child in the New York prison and Dickens's own childhood experience of prison visiting, the meeting between Oliver and the Jew in prison in the novel reminds the reader "dark and winding ways towards the cells", visualizing the fear of punishment through the "narrow steps" and the passage which leads to "a row of strong doors" (Dickens, 2003, p. 447). Oliver sees the horrible situation of the prisoner. As Dickens (2003) depicts:

The condemned criminal was seated on his bed, rocking himself from side to side, with a countenance more like that of a snared beast than the face of a man. His mind was evidently wandering to his old life, for he continued to mutter, without seeming conscious of their presence otherwise than as a part of his vision. (p. 448)

This scene synthesises imprisonment and madness, as the prisoner is "rocking himself from side to side" on his bed. The Jew now looks like a mad beast, rather than a human being. As Foucault has pointed out, "madmen remained monsters—-that is, etymologically, beings or things to be shown" (Foucault, 1988, p. 70). Insanity, like the criminal's "evil consciousness" in Dickens's narrative, is treated as one of many "forms of evil", as "Classicism felt a shame in the presence of the inhuman that the Renaissance had never experienced" (Foucault, 1988, p. 68). Dickens's own childhood situation and the scenes in American Notes and Oliver Twist all show the reader the way in which different forms of de-humanization in the 19th-century.

\section{Conclusions}

To conclude, Dickens’s figures of imprisonment and insanity are "symbolic" (Grossman, 2012, p. 155). These figures can be read as metaphors of de-humanization, with terms such as "pigs" or "beasts", applying to human beings. "Life in the city", as Duffy Jr. (1968) has stated, "so diminishes its inhabitants that the slum-dwellers are like rats and Fagin like a reptile and man like a dog or dog like a man in the Sikes relationship with his cur” (p. 408). As a novelist, Dickens's London and its Victorian prison scene in Oliver Twist demonstrate the same sense of "exclusion" and "silencing" (Sapouna, 2012, p. 613), as the readers can see in his New York prisons and mental institutions in American Notes. The sense of exclusion and silencing is symbolic, in a way which a human being becomes a non-being, or some sort of nothingness, being separated from humanity, and being pushed into darkness. This darkness comes to deform a person, showing primitive savagery through institutions. It reinforces the dialectic between order and disorder, civilization and crisis, performing the end and yet, the beginning of things, as a part of human life. 


\section{References}

Adrian, A. (1952). Dickens on American slavery: A carlylean slant. PMLA, 67(4), 315-329.

Baudelaire, C. (1995). The painter of modern life and other essays. (J. Mayne, Trans.). London: Phaidon.

Benjamin, W. (1973). Charles Baudelaire: A lyric poet in the era of high capitalism. (H. Zohn, Trans.). London: New Left Books.

Benson, A. C., \& Esher, V. (Eds.). (1907). The letters of Queen Victoria: A selection from Her Majesty's correspondence between the years 1837 and 1861, Volume I. London: John Murray.

Calder, A. (1987). Charles Dickens: A note. American Notes (pp. 7-10). Middlesex: Penguin.

Claybaugh, A. (2006). Toward a new transatlanticism: Dickens in the United States. Victorian Studies, 48(3), 439-460.

Defoe, D. (1998). Robinson crusoe. Oxford: Oxford University Press.

Dickens, C. (1987). American notes. J. S. Whitley, \& A. Goldman, (Eds.). Middlesex: Penguin.

Dickens, C. (2003). Oliver twist. P. Horne, (Ed.). London: Penguin.

Duffy, Jr. J. M. (1968). Another version of pastoral: Oliver twist. ELH, 35(3), 403-421.

Foucault, M. (1988). Madness and civilization. New York: Vintage.

Foucault, M. (1991). Discipline and punish: The birth of the prison. London: Penguin.

Frederick, K. C. (1966). The cold, cold hearth: Domestic strife in Oliver Twist. College English, 27(6), 465-470.

Freud, S. (1959). An autobiographical study: Inhibitions, symptoms and anxiety (The standard edition of the complete psychological works of Sigmund Freud, Vol. XX). (J. Strachey, Trans.). London: Hogarth.

Goldberg, M. (1972). From Bentham to Carlyle: Dickens’ political development. Journal of the History of Ideas, 33(1), 61-76.

Grossman, J. H. (2012). Charles Dickens's networks: Public transport and the novel. Oxford: Oxford University Press.

Grubb, G. G. (1950). The personal and literary relationships of Dickens and Poe (Part two: "English Notes" and "The Poet of America”). Nineteenth-Century Fiction, 5(2), 101-120.

Grubb, G. G. (1951). Dickens’ Western tour and the Cairo legend. Studies in Philology, 48(1), 87-97.

Heilman, R. B. (1947). The new world in Dickens's writings: Part two. Trollopain, 1(4), 11-26.

Kincaid, J. R. (1968). Laughter and “oliver twist”. PMLA, 83(1), 63-70.

Lankford, W. T. (1978). “The parish boy’s progress”: The evolving form of Oliver Twist. PMLA, 93(1), 20-32.

Meckier, J. (1984). Dickens discovers America, Dickens discovers Dickens: The first visit reconsidered. The Modern Language Review, 79(2), 266-277.

Poe, E. A. (1996). The man of the crowd. Edgar Allan Poe: Poetry, tales, and selected essays. New York: The Library of America. Pound, L. (1947). The American dialect of Charles Dickens. American Speech, 22(2), 124-130.

Sapouna, L. (2012). Classic texts: No. 16. Community Development Journal, 47(4), 612-617.

Stone, H. (1957). Dickens' use of his American experiences in Martin Chuzzlewit. PMLA, 72(3), 464-478.

Tagholm, R. (2001). Walking literary London. London: Garfield House.

Tomalin, C. (2012). Charles Dickens: A life. London: Penguin.

Waller, J. O. (1960). Charles Dickens and the American Civil War. Studies in Philology, 57(3), 535-548.

Werner, A., \& Williams, T. (2011). Dickens's Victorian London: 1839-1901. London: The Museum of London.

West, N. M. (1989). Order in disorder: Surrealism and “oliver twist”. South Atlantic Review, 54(2), 41-58. 